\title{
Raney ニッケル合金触媒によるメタノールの分解反応
}

\author{
(1985 年 10 月 23 日受理)
}

\author{
清 水 正 隆*・武 岡 壮
}

\begin{abstract}
メタノール分解反応用 Raney 型触媒の調製法を検討した。原料合金は $\mathrm{Ni}-\mathrm{Al}$ および $\mathrm{Ni}-\mathrm{Cu}-\mathrm{Al}$ 合 金である。

（1） $\mathrm{Ni}-\mathrm{Al}$ 合金から調製した $\mathrm{Ni}-\mathrm{Al}_{2} \mathrm{O}_{3}$ 触媒は分解反応に対する選択性が低く，活性劣化和よび炭 素析出がいちじるしかった。 $\mathrm{Cu}^{2+}$ アンミン錯イオンを含浸して調製した触媒（Cuに富む $\mathrm{Ni}-\mathrm{Cu}$ 合金， $\mathrm{Ni}$ および $\eta-\mathrm{Al}_{2} \mathrm{O}_{3}$ からなる) では, 分解反応に対する選択性が向上し, 活性劣化拉よび炭素析出の若 干の抑制がみられた。
\end{abstract}

（2） $\mathrm{Ni}-\mathrm{Cu}-\mathrm{Al}$ 合金から調製した $\mathrm{Ni}-\mathrm{Cu}-\mathrm{Al}_{2} \mathrm{O}_{3}$ 触媒 ( $\mathrm{Ni}$ に富む $\mathrm{Ni}-\mathrm{Cu}$ 合金, $\mathrm{Cu}$ および $\eta-\mathrm{Al}_{2} \mathrm{O}_{3}$ からなる）においては, 分解活性とジメチルエーテルの生成が優勢であり, 触媒の生成物による一特的 被毒および炭素析出に起因する活性劣化がみられた。C $\mathrm{Cu}^{2+}$ アンミン錯イオンを含浸して調製した触媒 は, 活性の向上がみられ, 一時的被毒による活性劣化を示した。そして,さらに $\mathrm{K}_{2} \mathrm{CO}_{3}$ を含浸して調製 した触媒では, ジメチルェーテルの生成の抑制と一時的被毒の解除がみられた。 Ni の Cuによる希釈 の度合が高い $\mathrm{Cu}^{2+}$ アンミン錯イオンを含浸して調製した触媒に和いては, 炭素析出量が少なかった。

\section{1 緒言}

メタノール分解反応はメタノールの利用技術の一つとして注目 され，すでに有効な触媒が見いだされている(12)。この反応をオン ボードリフォーミングおよびガスタービン発電などに適用する場 合の反応器の具備すべき要件は, 排気熱の効率のよい回収と負荷 変動下での至適反応温度の維持である ${ }^{3)}$ 。Raney 型触媒は熱交換 壁を触媒とするなどの形態で用いるこ'とが可能であるため, 上記 のシステムへの適用に有利であると思われる。本研究ではこのこ とを踏えて, Raney 型ニッケル系触媒の調製法を検討した。そし て, 上記のシステムにおいてて重要である分解反応に対する選択性 および耐久性と触媒調製法との関連についての知見を得たので報 告する。

\section{2 実験}

\section{1 触.媒調製}

2.1.1 原料合金：35\% Ni-Al 合金拈よび $25 \% \mathrm{Ni}-10 \% \mathrm{Cu}-$ $\mathrm{Al}$ 合金を作製した。所定量のニッケル, アルミニウムおよび銅を 炭素るつぼ中で溶融し, 放冷して上記の合金を得た。四1亿合金 断面の XMA の二次電子像を示す。 $\mathrm{Ni}-\mathrm{Al}$ 合金は $\mathrm{NiAl}_{3}$ および $\mathrm{Al}$ が主成分であり， $\mathrm{Ni}_{2} \mathrm{Al}_{3}$ の量は少なかった。 $\mathrm{Ni}-\mathrm{Cu}-\mathrm{Al}$ 合金中 のX線回折によって検出された相は $\mathrm{NiAl}_{3}, \mathrm{Ni}_{2} \mathrm{Al}_{3}, \mathrm{Cu}_{4} \mathrm{NiAl}_{7}$ 扰 よび Al であった。Young ら゙は $38.4 \% \mathrm{Ni}-10.8 \% \mathrm{Cu}-\mathrm{Al}$ 合金

東京農工大学工学部資源応用化学科, 184 小金井市中町

1）水野光一, 表面, 19, 513(1981).

2）今井哲也, 藤田浩, 飯田耕三, 厚川麻須美, 第 55 回触 媒討論会 (B )講演予稿集, p. 136(1985).

3) 村木秀昭, 化学工学, 48, 31(1984).
の XMA を用いた定量分析から $\mathrm{Ni}_{34} \mathrm{Cu}_{7} \mathrm{Al}_{59}$ [1], $\mathrm{Ni}_{23} \mathrm{CuAl}_{75}$ 〔2〕拉よび $\mathrm{NiCuAl}_{98}$ 〔3]の相を確認している。本研究で用い た Ni-Cu-Al 合金の各元素の特性 X線強度の相対値から, 図 $1 \mathrm{~b}$ に扣いて〔1], 〔2], 〔3〕に相当する相がみられたほか, $\mathrm{CuAl}_{2}$ 〔4〕（X線回折では検出されなかった）に相当する相もみられ た。〔1〕は $\mathrm{Ni}_{2} \mathrm{Al}_{3}$ と $\mathrm{Cu}_{4} \mathrm{NiAl}_{7}$ の混合相であり,〔2〕の相は $\mathrm{NiAl}_{3}$ と $\mathrm{CuAl}_{2}$ の混合相であると推定された。後に述べるよう に, $\mathrm{Ni}_{2} \mathrm{Al}_{3}$ および $\mathrm{Cu}_{4} \mathrm{NiAl}_{7}$ は合金の展開処理後る残存した。

2.1.2 触媒: 上記の合金を 8〜10メッシュに破砕して以下の 触媒を調製した。いずれの触媒についても展開処理, 水洗, 乾燥 $\left(\mathrm{N}_{2}\right.$ 気流中 $\left.60^{\circ} \mathrm{C}\right)$ ののち, 室温 $350^{\circ} \mathrm{C}$ の温度範囲で段階的に昇

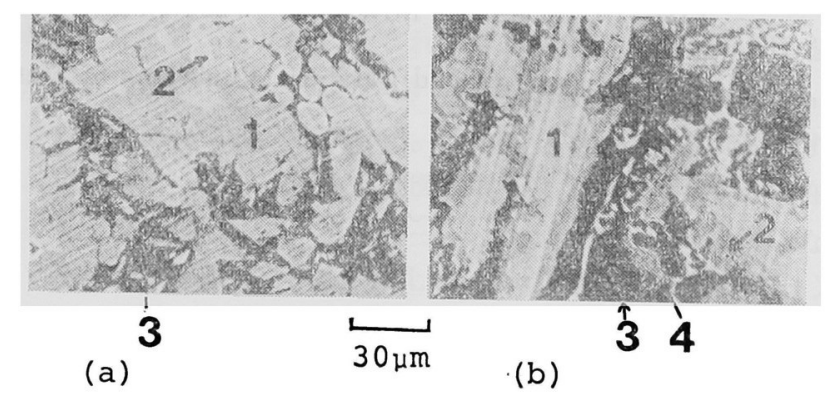

Fig. 1 EPMA secondary electron image of starting alloys

(a) $\mathrm{Ni}-\mathrm{Al}$ alloy; 1, 2, 3 correspod to $\mathrm{NiAl}_{3}, \mathrm{Ni}_{2} \mathrm{Al}_{3}$, Al-Ni solid soln. respectively

(b) $\mathrm{Ni}-\mathrm{Cu}-\mathrm{Al}$ alloy; 1, 2, 3, 4 correspond to [1], $[2],[3],[4]$, shown in 2.1 .1 , respectively

4) D. J. Young, M. S. Wainwright, J. Catal., 64, 116 (1980). 
Table 1 X-ray diffraction analysis of alloys Alloy

Phases detected

$35 \% \mathrm{Ni}-65 \% \mathrm{Al}$ $\mathrm{NiAl}_{3}, \quad \mathrm{Ni}_{2} \mathrm{Al}_{3}, \mathrm{Al}$

$25 \% \mathrm{Ni}-10 \% \mathrm{Cu}-65 \% \mathrm{Al} \quad \mathrm{NiAl}_{3}, \mathrm{Ni}_{2} \mathrm{Al}_{3}, \mathrm{Cu}_{4} \mathrm{NiAl}_{7}, \mathrm{Al}$

温して酸化した。酸化にさいして，各温度段階で酸素濃度を 0.5 〜21\%まで変化させた。その後, 所定の温度で所定時間空気中で 焼成した。

（1） $\mathrm{Ni}-\mathrm{Al}$ 合金を用いた触媒：(a) $\mathrm{Ni}-\mathrm{Al}_{2} \mathrm{O}_{3}$ 触媒 : $2.6 \%$ $\mathrm{NaOH}$ 水溶液を用いて $80^{\circ} \mathrm{C} て ゙ 120$ 分間展開処理を行なった。 $580^{\circ} \mathrm{C}$ で 5 時間焼成した。(b) $\mathrm{Ni}-\mathrm{Al}_{2} \mathrm{O}_{3}-\mathrm{Cu}^{2+}$ 触媒 : (a) で得 た酸化物を $\mathrm{Cu}^{2+}$ アンミン錯イオン溶液占) に浸漬し, 乾燥 (空気流 中 $110^{\circ} \mathrm{C}, 2$ 時間）後，空気流中 $400^{\circ} \mathrm{C}$ で 2 時間焼成した。

（2） $\mathrm{Ni}-\mathrm{Cu}-\mathrm{Al}$ 合金を用いた触媒: (a) $\mathrm{Ni}-\mathrm{Cu}-\mathrm{Al}_{2} \mathrm{O}_{3}$ 触 媒: $2.6 \% \mathrm{NaOH}$ 水溶液を用いて $80^{\circ} \mathrm{C}$ で 150 分間展開处理を行 なった。 $580^{\circ} \mathrm{C}$ で5 時間焼成した。(b) Ni-Cu- $\mathrm{Al}_{2} \mathrm{O}_{3}-\mathrm{Cu}^{2+}$ 触 媒: (a) で得た酸化物を $\mathrm{Cu}^{2+}$ アンミン錯イオン溶液に浸潰し て, ( (1)-(b) と同様に処理して調製した。 (c) Ni-Cu- $\mathrm{Al}_{2} \mathrm{O}_{3}-\mathrm{K}$ (0.2) 触媒: (a) で得た酸化物を $0.2 \% \mathrm{~K}_{2} \mathrm{CO}_{3}$ 水溶液に 2 時間 浸漬し, 赎燥 (空気流中 $110^{\circ} \mathrm{C}$ で 2 時間) 後, $500^{\circ} \mathrm{C}$ で 3 時間焼 成した。（d） $\mathrm{Ni}-\mathrm{Cu}-\mathrm{Al}_{2} \mathrm{O}_{3}-\mathrm{Cu}^{2+}-\mathrm{K}$ 触媒：（b）で調製したもの を $0.2 \%$ および $0.3 \% \mathrm{~K}_{2} \mathrm{CO}_{3}$ 水溶液に 2 時間浸漬し，(c) の場 合と同様に処理した。扮の括の, $\mathrm{Ni}-\mathrm{Cu}-\mathrm{Al}_{2} \mathrm{O}_{3}-\mathrm{Cu}^{2+}-\mathrm{K}(0.2)$, $\mathrm{Ni}-\mathrm{Cu}-\mathrm{Al}_{2} \mathrm{O}_{3}-\mathrm{Cu}^{2+}-\mathrm{K}(0.3)$ とする。

図 2 は $\mathrm{Ni}-\mathrm{Cu}-\mathrm{Al}$ 合金を展開，酸化扰よび焼成処理した試料の 断面の顕微鏡写真である。触媒原料合金を熱交換壁に接合させる ことによって，すぐれた伝熱特性を有する反応器が得られること が予想される。

\section{$2: 2$ 反応実験}

固定層流通反応装置を用いた。反応管は内径 $15 \mathrm{~mm}$ の石英が ラス製である。反応管内の軸方向温度分布を平滑化するために， $2 \mathrm{~g}$ の触媒を 6 層に分けて充媜し, 各触媒層の間には 8 10 メッ シュの破碎石英ガラスを充填した。2.1.2 に記した触媒のほか, 比較のために， $\mathrm{Cu}-\mathrm{Zn}$ 触媒 ( $\mathrm{G}-66 \mathrm{~B}, 0.8 \mathrm{~g})$ 㸭よび既報6で述べ た Raney 銅触媒を用いた。いずれの触媒も反応に供する前に $200 \sim 350^{\circ} \mathrm{C}$ の温度範囲で段階的に昇温し， $350^{\circ} \mathrm{C}$ で 2 時間保持し

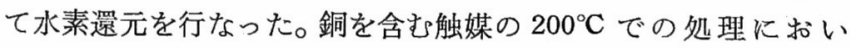
て, 水素濃度を $2 \%$ から $10 \%$ (希釈ガス $\mathrm{N}_{2}$ ) に段階的に変化さ せたのち純水素に切り替光たっっいで, Raney 銅触媒特よび $\mathrm{Cu}$ $Z n$ 触媒を除く触媒を $500^{\circ} \mathrm{C}$ で 12 時間水素気流中で処理した。 反応条件は温度 $300 \sim 400^{\circ} \mathrm{C}$, メタノール分圧 0.5 ( $\mathrm{N}_{2}$ で希釈), LHSV $=12.9 \mathrm{~h}^{-1}$ （触媒充填容積基準）である。メタノールは市 販特級品をそのまま用いた。生成物の分析はガスクロマトグラフ ィーによって行なった。液状物は1ープロパノールコールドトラ ップで捕集し，FID ガスクロマトグラフ $\left(\mathrm{BX}-10,90^{\circ} \mathrm{C}\right)$ で，ガ ス成分は TCD ガスクロマトグラフ (活性炭, $80^{\circ} \mathrm{C}$ ) 扩よび FID ガスクロマトグラフ (Porapak R, 90 $\mathrm{C}$ ) で分析した。

\section{3 原料合金および触媒の分析}

\section{(1) X線回折}

理学電機製 SG-9 型 $\mathrm{X}$ 線回折装置 ( $\mathrm{Cu} K_{\boldsymbol{a}}$ 線) を用いた。結晶

5) $6 \mathrm{~mol} \cdot \mathrm{dm}^{-3} \mathrm{NH}_{4} \mathrm{OH}$ 飞 $\mathrm{Cu}(\mathrm{OH})_{2}$ を飽和まで溶解して調 製した。

6) 清水正隆, 武岡 壮, 日化, 1981, 912.

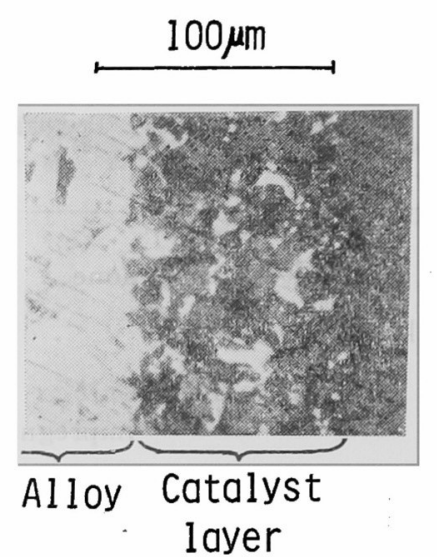

Fig. 2 Photograph of the cross section of the catalyst from $\mathrm{Ni}-\mathrm{Cu}-\mathrm{Al}$ alloy

相の同定和よび触媒に和ける $\mathrm{Ni}$ 和よび $\mathrm{Cu}$ の格子定数の測定を 行なった。回折角の測定にはケイ素（添川理化学製 200 メッシュ 以下）を標準物質として用いた。また，触媒に含まれる $\mathrm{Cu}$ に富 む $\mathrm{Ni}-\mathrm{Cu}$ 合金と $\mathrm{Ni}$ との量比 $\left(\mathrm{Ni}-\mathrm{Al}_{2} \mathrm{O}_{3}-\mathrm{Cu}^{2+}\right.$ 触媒) およびCu と $\mathrm{Ni}$ 亿富守 $\mathrm{Ni}-\mathrm{Cu}$ 合金との量比 $\left(\mathrm{Ni}-\mathrm{Cu}-\mathrm{Al}_{2} \mathrm{O}_{3}, \mathrm{Ni}-\mathrm{Cu}-\right.$ $\mathrm{Al}_{2} \mathrm{O}_{3}-\mathrm{Cu}^{2+}$ 触媒）を求めた。そのさい $\mathrm{Ni} と \mathrm{Cu}$ の混合試料によ る検量線を用いた7)。

(2) XMA 分析

島津製作所製 EMX-SM 型X線マイクロアナライザーを用い て，原料合金断面の分析を行なった。

（3）比表面積扣よび水素吸着量

$\mathrm{Ni}-\mathrm{Cu}-\mathrm{Al}$ 合金から調製した, $500^{\circ} \mathrm{C}$ で 12 時間水素処理後の 触媒について測定した。比表面積は液体窒素温度における窒素吸 着量を測定して求めた。試料の排気処理は $400^{\circ} \mathrm{C} て ゙ 30$ 分間行な った。水素吸着量の測定は室温でつぎのょうに行なった。200 $\mathrm{mmHg}$ までの压力範囲で吸着量を測定したのち, 至温で 10 分間 排気を行ない, 再度吸着量を測定した。1 回目と 2 回目の測定値 の差を水素吸着とした。試料の前処理は水素気流中 $400^{\circ} \mathrm{C}$ で 30 分間処理し，同温度で 1 時間排気して行なった。

(4) 触媒の炭素含有量

柳本製作所製の $\mathrm{CHN}$ コーダーを用いて, $\mathrm{Ni}-\mathrm{Cu}-\mathrm{Al}$ 合金がら 調製した触媒の反応後の炭素含有量を測定した。触媒を酸素一 リウム気流中 $860^{\circ} \mathrm{C}$ で燃焼させ, 二酸化炭素を測定する方法で炭 素の定量を行なった。

\section{3 結 果之考察}

\section{1 触媒の X 線回折}

表 2 に $500^{\circ} \mathrm{C}$ で 12 時間水素流中で処理したのちの各触媒の $\mathrm{X}$ 線回折の結果を示す。

（1） $\mathrm{Ni}-\mathrm{Al}$ 合金を用いた場合： $\mathrm{Ni}-\mathrm{Al}_{2} \mathrm{O}_{3}$ 触媒においては $\mathrm{Ni}$ 特よび $\eta-\mathrm{Al}_{2} \mathrm{O}_{3}$ が検出された。 $\mathrm{Ni}-\mathrm{Al}_{2} \mathrm{O}_{3}-\mathrm{Cu}^{2+}$ 触媒において は $\mathrm{Ni}, \eta-\mathrm{Al}_{2} \mathrm{O}_{3}$ に加兄て $\mathrm{Cu}$ に富さ $\mathrm{Ni}-\mathrm{Cu}$ 合金の回折線が文ら れた。表 2 亿示すように, $\mathrm{Ni}-\mathrm{Cu}$ 合金の格子定数 $\left(a_{0}\right)$ は 3.606

7）触媒中の $\mathrm{Ni}-\mathrm{Cu}$ 合金は，後に述べるように $\mathrm{Cu}$ または $\mathrm{Ni}$ を 12 atom\% 以下含む. 検量線を用いる場合， $\mathrm{Cu}$ 亿 富を $\mathrm{Ni}-\mathrm{Cu}$ 合金を $\mathrm{Cu}$ とし, $\mathrm{Ni}$ に富む $\mathrm{Ni}-\mathrm{Cu}$ 合金を $\mathrm{Ni}$ とした. $\mathrm{Ni}$ と $\mathrm{Cu}$ はX線吸収係数が約 $14 \%$ 異なる ので，求めた量比は半定量的な值である. 


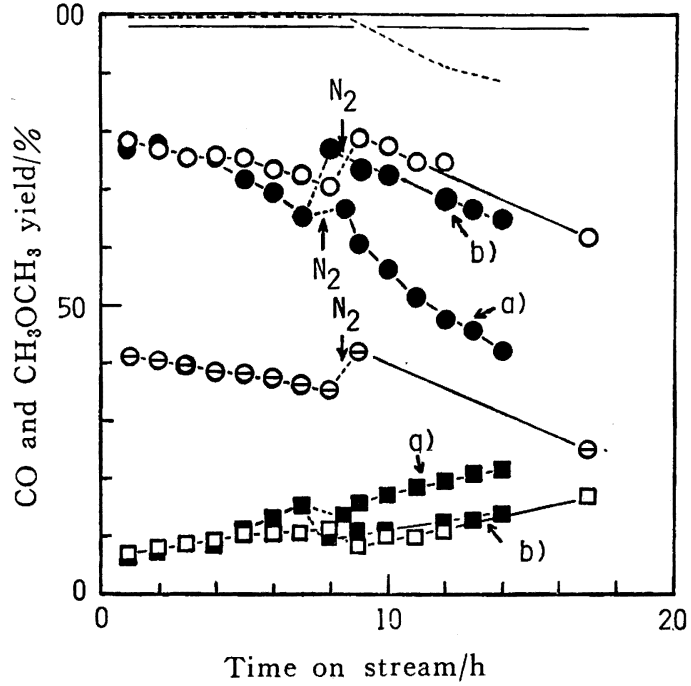

Fig. 3 Activity change of the catalysts prepared from $\mathrm{Ni}-\mathrm{Cu}-\mathrm{Al}$ alloy

$\mathrm{CO}$ yíeld ;

$\mathrm{O}: \mathrm{Ni}-\mathrm{Cu}-\mathrm{Al}_{2} \mathrm{O}_{3}-\mathrm{Cu}^{2+}$

$\Theta$ : Values at $300^{\circ} \mathrm{C}$ for $\mathrm{Ni}-\mathrm{Cu}-\mathrm{Al}_{2} \mathrm{O}_{3}-\mathrm{Cu}^{2+}$

: $\mathrm{Ni}-\mathrm{Cu}-\mathrm{Al}_{2} \mathrm{O}_{3}$, a ) : After purged with $\mathrm{N}_{2}$, b) : After treatment with $\mathrm{H}_{2}$ at $400^{\circ} \mathrm{C}$ $\mathrm{CH}_{3} \mathrm{OCH}_{3}$ yield ;

$\square: \mathrm{Ni}-\mathrm{Cu}-\mathrm{Al}_{2} \mathrm{O}_{3}-\mathrm{Cu}^{2+}$

a $\mathrm{Ni}-\mathrm{Cu}-\mathrm{Al}_{2} \mathrm{O}_{3}$, a ) : After purged with $\mathrm{N}_{2}$, b) : After treatment with $\mathrm{H}_{2}$ at $400^{\circ} \mathrm{C}$

Methanol conversion ;

: $\mathrm{Ni}-\mathrm{Cu}-\mathrm{Al}_{2} \mathrm{O}_{3}-\mathrm{Cu}^{2+}$

....: $\mathrm{Ni}-\mathrm{Cu}-\mathrm{Al}_{2} \mathrm{O}_{3}$

$\mathrm{N}_{2}$ : Purged with $\mathrm{N}_{2}$

$\downarrow$

增大した。炭素析出は後者にくらべて若干減少したが, 多量であ った。選択性のいちじるしい変化は $\mathrm{Ni}$ 表面に扣ける $\mathrm{Ni}-\mathrm{Cu}$ 合 金の形成によると思われる。しかし，いちじるしい炭素析出がみ られることから， $\mathrm{Ni}$ の表面が $\mathrm{Ni}-\mathrm{Cu}$ 合金によって均一に招拈わ れていないことを示唆する。 $\mathrm{Ni}-\mathrm{Cu}-\mathrm{Al}_{2} \mathrm{O}_{3}-\mathrm{Cu}^{2+}$ 触媒拈よび $\mathrm{Ni}-$ $\mathrm{Cu}-\mathrm{Al}_{2} \mathrm{O}_{3}$ 触媒は両者とも同様な選択性を示した。前者は後者に くらべて高い活性を示し, 銅が活性の向上に寄与していることが わかった。Raney 銅は高いメタノール転化率を示したが，分解反 応に対する選択性は低くギ酸メチルおよび $\mathrm{CO}_{2}$ の生成が顕著で あった。これに対して, 遊離の銅を含む $\mathrm{Ni}-\mathrm{Cu}-\mathrm{Al}_{2} \mathrm{O}_{3}-\mathrm{Cu}^{2+}$ 触媒 に打いてはギ酸メチルは検出されなかった。

3.2.3 カリウムの添加効果— Ni-Cu-Al 合金を用いた場合: $\mathrm{K}_{2} \mathrm{CO}_{3}$ を含浸した触媒において $\mathrm{CH}_{3} \mathrm{OCH}_{3}$ の生成が抑制され た。

また，カリウム濃度を高めた触媒の分解活性は向上した。これ らのことはカリウムによるアルミナの脱水反応活性の抑制および 分解活性の促進による10) と考光られる。

\section{3 活性経時变化}

前に述べたように， $\mathrm{Ni}-\mathrm{Al}$ 合金を用いた場合反応管を開塞する ほどのいちじるしい炭素析出がみられ，活性劣化もいちじるしか った。 $\mathrm{Ni}-\mathrm{Cu}-\mathrm{Al}$ 合金を用いた場合の $350^{\circ} \mathrm{C}$ での活性経時変化を

10）水野光一, 周 沢興, 鈴木正臣, 第 11 回石油化学討諭会 予稿集，p.82(1981).

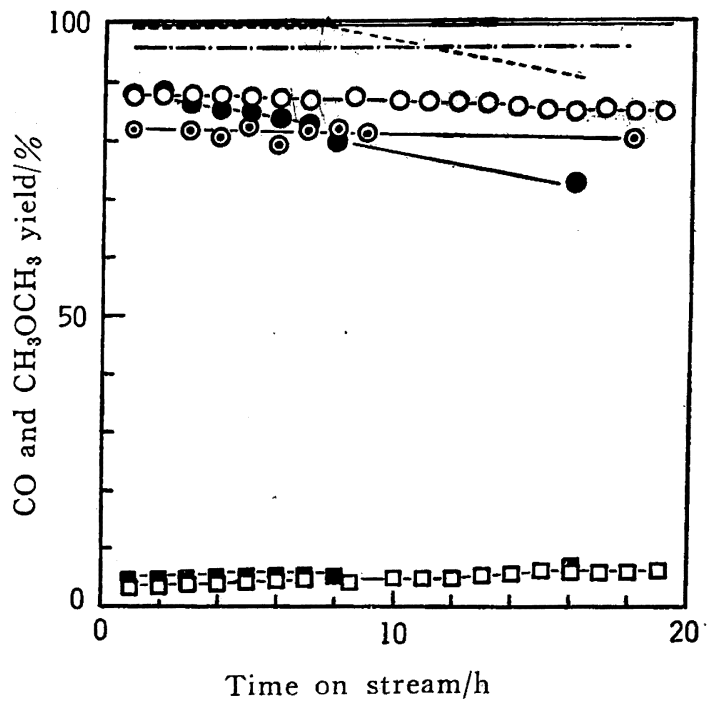

Fig. 4 Effect of the addition of $\mathrm{K}_{2} \mathrm{CO}_{3}$

CO yield;

$\mathrm{O}: \mathrm{Ni}-\mathrm{Cu}-\mathrm{Al}_{2} \mathrm{O}_{3}-\mathrm{Cu}^{2+}-\mathrm{K}(0.3)$

- : $\mathrm{Ni}-\mathrm{Cu}-\mathrm{Al}_{2} \mathrm{O}_{3}-\mathrm{Cu}^{2+}-\mathrm{K}(0.2)$

: $\mathrm{Ni}-\mathrm{Cu}-\mathrm{Al}_{2} \mathrm{O}_{3}-\mathrm{K}(0.2)$

$\mathrm{CH}_{3} \mathrm{OCH}_{3}$ yield;
$\square: \mathrm{Ni}-\mathrm{Cu}-\mathrm{Al}_{2} \mathrm{O}_{3}-\mathrm{Cu}^{2+}-\mathrm{K}(0.3)$

: $\mathrm{Ni}-\mathrm{Cu}-\mathrm{Al}_{2} \mathrm{O}_{3}-\mathrm{K}(0.2)$

Methanol conversion;

$$
\begin{aligned}
- & \mathrm{Ni}-\mathrm{Cu}-\mathrm{Al}_{2} \mathrm{O}_{3} \mathrm{Cu}^{2+}-\mathrm{K}(0.3) \\
-\cdot-: & \mathrm{Ni}-\mathrm{Cu}-\mathrm{Al}_{2} \mathrm{O}_{3} \mathrm{Cu}^{2+}-\mathrm{K}(0.2) \\
\cdots \cdots: & \mathrm{Ni}-\mathrm{Cu}-\mathrm{Al}_{2} \mathrm{O}_{3}-\mathrm{K}(0.2)
\end{aligned}
$$

図3，4 亿示す。図3 亿示すよらに, $\mathrm{Ni}-\mathrm{Cu}-\mathrm{Al}_{2} \mathrm{O}_{3}$ 触媒打よび $\mathrm{Ni}-\mathrm{Cu}-\mathrm{Al}_{2} \mathrm{O}_{3}-\mathrm{Cu}^{2+}$ 触媒とも時間とともに分解活性はいちじるし く低下し, $\mathrm{CH}_{3} \mathrm{OCH}_{3}$ の生成率が増大した。 $\mathrm{Ni}-\mathrm{Cu}-\mathrm{Al}_{2} \mathrm{O}_{3}-\mathrm{Cu}^{2+}$ 触媒に扰いてはメタノールの供給を止めて, 窒素のみを流したの ちふたたびメタノールを供給したところ, 分解活性は反応初期の 值まで回復した。その後ふたたび分解活性の劣化と $\mathrm{CH}_{3} \mathrm{OCH}_{3}$ の 選択率の增大がみられた。 $\mathrm{Ni}-\mathrm{Cu}-\mathrm{Al}_{2} \mathrm{O}_{3}$ 触媒に打いては窒素パー ジによる分解活性の上昇は少なかった。カリウムを添加した触媒 は添加しない触媒にくらべて活性劣化が大幅に軽減した（図 4)。 窒素パージによる分解活性の変化はほとんどみられなかった。 $\mathrm{Ni}-\mathrm{Cu}-\mathrm{Al}_{2} \mathrm{O}_{3}-\mathrm{Cu}^{2+}-\mathrm{K}$ 触媒の活性劣化は $\mathrm{Ni}-\mathrm{Cu}-\mathrm{Al}_{2} \mathrm{O}_{3}-\mathrm{K}$ にくら ベていちじるしく小さかった。

（1）触媒の一時的被毒：カリウムを添加しない触媒の活性経 時変化の样相からつぎのよらに考察された。 $\mathrm{Ni}-\mathrm{Cu}-\mathrm{Al}_{2} \mathrm{O}_{3}-\mathrm{Cu}^{2+}$ 触媒に打いて，窒素パージに上る分解活性の回復がみられたこと から，分解活性の劣化は窒素パージによって脱離可能な吸着物質 による分解活性点の一時的被毒によることを示す。これに対し $\tau, \mathrm{Ni}-\mathrm{Cu}-\mathrm{Al}_{2} \mathrm{O}_{3}$ 触媒に括ける分解活性の劣化は窒素バージによ って脱離する物質と脱離しない物質とによる分解活性点の被毒に よると考兄られる ${ }^{11)}$ 。分解活性の劣化にともなら $\mathrm{CH}_{3} \mathrm{OCH}_{3}$ の生 成率の增大は分解活性を担ら $\mathrm{Ni}-\mathrm{Cu}$ 合金拉よび銅が被毒されて いくにつれて $\mathrm{Al}_{2} \mathrm{O}_{3}$ 上での脱水反応速度が増加することによる と考察された。

11）反応前後において，X線回折による $\mathrm{Ni}-\mathrm{Cu}$ 合金および銅 の結晶子径の変化がみられなかったことからこれらのシ ンタリングによる劣化は除外される。 
Table 4 Carbon content of the catalysts prepared from $\mathrm{Ni}-\mathrm{Cu}-\mathrm{Al}$ alloy

Catalyst Carbon content $\%$

$\begin{array}{ll}\mathrm{Ni}-\mathrm{Cu}-\mathrm{Al}_{2} \mathrm{O}_{3} & 1.30 \\ \mathrm{Ni}-\mathrm{Cu}-\mathrm{Al}_{2} \mathrm{O}_{3}-\mathrm{K}(0.2) & 1.31 \\ \mathrm{Ni}-\mathrm{Cu}-\mathrm{Al}_{2} \mathrm{O}_{3}-\mathrm{Cu}^{2+} & 0.70 \\ \mathrm{Ni}-\mathrm{Cu}-\mathrm{Al}_{2} \mathrm{O}_{3}-\mathrm{Cu}^{2+}-\mathrm{K}(0.2) & 0.67 \\ \mathrm{Ni}-\mathrm{Cu}-\mathrm{Al}_{2} \mathrm{O}_{3}-\mathrm{Cu}^{2+}-\mathrm{K}(0.3) & 0.66\end{array}$

カリウムを添加した触某においては分解活性の劣化が反応途中 での窒素パージの前後で連続的であったことと，カリウムを添加 しない触媒にくらべて劣化の速度がゆるやかであったことから触 腜の一時的被毒が解除されたと考えられる。分解活性点の一時的 被毒の原因として，メタノール12)あるいは $\mathrm{CO}^{10)}$ などの生成物の 強吸着が考えられる。 $\mathrm{Ni}-\mathrm{Cu}-\mathrm{Al}_{2} \mathrm{O}_{3}-\mathrm{Cu}^{2+}$ 触媒に打いてメタノー ル転化率の低い $300^{\circ} \mathrm{C}$ での活性劣化が $350^{\circ} \mathrm{C}$ でのそれにくらべ て顕著でない（図 3) ことから，メタノールによる被毒は一応除 外されると思われる。 $\mathrm{Ni} / \mathrm{Al}_{2} \mathrm{O}_{3}$ 触媒による分解反応は $\mathrm{CO}$ によ る被毒効果が大きく，カリウムの添加により $\mathrm{CO}$ 被毒が抑制され たとされる ${ }^{10)}$ 。本研究の触媒に扣いてみられる一時的被毒は CO によると一応考学られる。しかしこの点はさらに検討の余地が

12) T. Inui, M. Suehiro, S. Yamamoto, K. Ohmura, Y. Takegami, J. Jpn. Petrol. Inst., 25, 121(1982).
Table $5 \quad \mathrm{H}_{2}$ adsorption and BET surface area for the catalysts prepared from $\mathrm{Ni}-\mathrm{Cu}-\mathrm{Al}$ alloy

\begin{tabular}{lcc}
\multicolumn{1}{c}{ Catalyst } & $\begin{array}{c}\mathrm{H}_{2} \text { uptake/ } \\
\mu \text { mol } / \mathrm{g}\end{array}$ & $\begin{array}{c}\mathrm{BET} \text { surface } \\
\text { area/m } / \mathrm{g}\end{array}$ \\
\hline $\mathrm{Ni}-\mathrm{Cu}-\mathrm{Al}_{2} \mathrm{O}_{3}$ & 47.7 & 78 \\
$\mathrm{Ni}-\mathrm{Cu}-\mathrm{Al}_{2} \mathrm{O}_{3}-\mathrm{Cu}^{2+}$ & 37.5 & 76 \\
$\mathrm{Ni}-\mathrm{Cu}-\mathrm{Al}_{2} \mathrm{O}_{3}-\mathrm{Cu}^{2+}-\mathrm{K}(0.2)$ & 36.6 & 75
\end{tabular}

あろら。

(2) 触媒の炭素による被毒 : 図 3 に $\mathrm{Ni}-\mathrm{Cu}-\mathrm{Al}_{2} \mathrm{O}_{3}$ 触媒につ いて反応途中で $400^{\circ} \mathrm{C} ， 1$ 時間水素処理した後の活性経時変化を 示す。水素処理によって分解活性は反応初期の值まで回復した。 表 4 に示すように, $\mathrm{Ni}-\mathrm{Cu}-\mathrm{Al}_{2} \mathrm{O}_{3}$ 系の触媒は $\mathrm{Ni}-\mathrm{Cu}-\mathrm{Al}_{2} \mathrm{O}_{3}-\mathrm{Cu}^{2+}$ 系の触媒にくらべて反応後の炭素含有量が大であった。これらの ことから，窒素パージによって脱離しない被毒物質は析出炭素で あると考えられる。また，表 5 に示すよらに後者の方が水素吸着 量が小さいことから, 表面ニッケルの銅による希釈の度合が後者 で大きいことがわかった。ニッケルの銅による希釈の度合が大き いほど CO の解離が抑制されると推定される。このことから， $\mathrm{Ni}-\mathrm{Cu}-\mathrm{Al}_{2} \mathrm{O}_{3}-\mathrm{Cu}^{2+}$ 系触媒に扣いて析出炭素量が減少し, 活性点 の炭素による被毒による失活が抑えられたと考えられる。

(1984 年 10 月, 昭和 59 年度触媒研究発表会一部発表)

\title{
Decomposition of Methanol over Raney Nickel Alloy Catalysts
}

\author{
Masataka SHIMizU* and So $\mathrm{T}_{\mathrm{AKEOKA}}$ \\ Department of Applied Chemistry for Resouses, Faculty of Technology, \\ Tokyo University of Agriculture and Technology; \\ Naka-machi, Koganei-shi 184 Japan
}

The preparative methods of the Raney-type catalysts for decomposition of methanol were examined. $\mathrm{Ni}-\mathrm{Al}$ and $\mathrm{Ni}-\mathrm{Cu}-\mathrm{Al}$ alloys were used as catalyst raw materials.

The catalyst oxide precursors were prepared by leaching the Raney alloys with dilute $\mathrm{NaOH}$ aq. soln., followed by oxidation and calcination in air. Addition of $\mathrm{Cu}$ and $\mathrm{K}$ as promoter were carried out by impregnation of the oxide precursors with $\mathrm{Cu}^{2+}$ ammine complex ion and $\mathrm{K}_{2} \mathrm{CO}_{3}$ aq. soln., respectively. For $\mathrm{Ni}-\mathrm{Al}_{2} \mathrm{O}_{3}$ catalyst prepared from $\mathrm{Ni}-\mathrm{Al}$ alloy, low selectivity toward decomposition of methanol was observed, and extensive deactivation and carbon deposition occured. Addition of $\mathrm{Cu}$, the constituents of resulting catalyst were copper-rich $\mathrm{Ni}-\mathrm{Cu}$ alloy, $\mathrm{Ni}$ and $\eta-\mathrm{Al}_{2} \mathrm{O}_{3}$, was found to improve selectivity toward decomposition of methanol markedly and to reduce deactivation and carbon deposition to some extent. For $\mathrm{Ni}-\mathrm{Cu}-\mathrm{Al}_{2} \mathrm{O}_{3}$ catalyst prepared from $\mathrm{Ni}-\mathrm{Cu}-\mathrm{Al}$ alloy which consists of nickel-rich $\mathrm{Ni}-\mathrm{Cu}$ alloy, $\mathrm{Cu}$ and $\eta-\mathrm{Al}_{2} \mathrm{O}_{3}$, decomposition of methanol and formation of dimethyl ether were predominant. And deactivation due to reversible poisoning by reaction product and carbon deposition was observed (Fig. 3). On the other hand, the deactivation of the $\mathrm{Cu}$ added catalyst, as prepared by impregnation of $\mathrm{Ni}-\mathrm{Cu}-\mathrm{Al}_{2} \mathrm{O}_{3}$ precursor with $\mathrm{Cu}^{2+}$, was found to be due to reversible poisoning. And the activity of the catalyst was higher than $\mathrm{Ni}-\mathrm{Cu}-\mathrm{Al}_{2} \mathrm{O}_{3}$ catalyst (Table 3). For the catalysts impregnated with $\mathrm{K}_{2} \mathrm{CO}_{3}$, the suppression of dimethyl ether formation and the elimination of reversible poisoning were observed (Fig. 4). For the catalysts impregnated with $\mathrm{Cu}^{2+}$, carbon deposition was suppressed. 